\title{
6
}

\section{Writing after Colonialism: Crick Crack, Monkey and Beka Lamb}

In national allegories, women became the territory over which the quest for (male) national identity passed, or, at best . . . the space of loss and of all that lies outside the male games of rivalry and revenge. . . . Under those circumstances, a national identity could not but be a problematic terrain for women novelists, although it was not something they could avoid.

- Jean Franco, Plotting Women

When yuh succumb to certain tings in silence yuh build up di power of di oppressor to exploit a next person.

-Sistren, Lionheart Gal

To consider the question of gender and subjectivity in modernist discourse is also to confront the ambiguous role women play in the construction of national identity. I have already hinted at this ambiguity in the previous chapters: in the central (male) texts of Caribbean modernism women either signify the social space over which the colonizer and the colonized struggle or function as what Franco, in the epigraph above, calls a space of loss. In many of the novels discussed earlier, women are often confined to private spaces, largely excludedlike Sophia in Carpentier's El siglo-from the historical events that obsess and overdetermine the men's lives and experiences. Alternatively, as in the case of Lamming's In the Castle of My Skin, while the figure of the mother represents the utopian space of the nation, of 
home and belonging, the mother is still notable for her prolonged silence and subordination to the son's quest for identity. Where women embrace modernity and modernization as a way out of the dominant patriarchal structures, often defined as tradition (Selvon's Seeta is an apt example here), they are seen not as agents of social change, but as destabilizers of the family and the cultural body. Ultimately, as Merle Kinbona discovers in The Chosen Place, the end of colonialism does not rescue women from their historical confinement-they still remain modernism's "other," excluded or marginalized from the signifying systems of the new nation. ${ }^{1}$

In writing about gender and representation in colonial and postcolonial Mexican society, Jean Franco observes that the relationship between women and the discourse of national identity and modernity was different from that of men and hence demanded a reconsideration of the diverse configuration of colonial subjects and the articulation of gender and subjectivity in the terrain of the nation. If nationalism and modernization constituted the master narratives, and hence the symbolic systems that cemented colonial and postcolonial societies, argues Franco, these narratives also "plotted women differently into the social text." 2 In the circumstances, women writers-unable to find a detour around the issue of the new nation and determined to tell their own stories within the national signified-have provided inevitable revisionings of the Caribbean narrative.

It is true that Caribbean male writers such as Earl Lovelace and Michael Thelwell have written trenchant critiques of what Fanon once called "the pitfalls of national consciousness," but it is the emergence of the Caribbean woman writer in the post-independence period which forces us to reconsider the very definition of modernity and its concordant discourse on national identity. ${ }^{3}$ For if the colonized body has been equated with the mother who has to be rescued from the conqueror and restored to her true identity and her real cultural norms, it is pertinent to question how women writers perceive this mother figure and how they locate her in the signifying systems of the colony and the new nation. As Olive Senior has succinctly noted, the emergence of the Caribbean woman writer has opened a completely xii.

1. Jean Franco, Plotting Women: Gender and Representation in Mexico (London: Verso, 1989), p.

2. Franco, p. xii.

3. Frantz Fanon, The Wretched of the Earth, trans. Constance Farrington (New York: Grove Press, 1968), pp. 148-205. 
new approach to the topic of the Caribbean mother and the cultural forms with which she is associated. ${ }^{4}$ Caribbean women writers compel us to examine the relationship between national identity, gender, and subjectivity in Caribbean discourse.

Moreover, in challenging male definitions of the nation, its past history, present crisis, and future destiny, and by underscoring the crucial relationship between gender and identity, Caribbean women writers are redefining Caribbean literary history. According to Carole Boyce Davies, "A substantial number of women writers, living both at home and abroad, have emerged, giving different shape and voice to this literature and challenging the preeminence of the largely male writers whom we used to think of as 'Caribbean literature.' The reality of gender presents, perhaps, the crucial difference between this group of writers and the preceding generation." 5 Apart from forcing us to question the meaning of the central terms in colonial and postcolonial discourse-terms such as culture, nation, and selfhood-Caribbean women's writing has also raised the question of silence and the absence of Caliban's woman-"an absence which is functional to the new secularizing schema by which the peoples of Western Europe legitimized their global expansion," according to Sylvia Wynter. ${ }^{6}$ In other words, whereas male discourse in the Caribbean was previously obsessed with the Prospero/Caliban dialectic and the slave's inheritance of his master's language, women writers strive to underscore the converse process - the absence of the female subject and its silencing in the master/slave dialectic.

Carole Davies and Elaine Fido have provided us with a limpid definition of absence and voicelessness as preconditions for a revisionist female discourse in the Caribbean:

The concept of voicelessness necessarily informs any discussion of Caribbean women and literature. It is a crucial consideration because it is out of this voicelessness and consequent absence that an understanding of our creativity in written expression emerges. By voicelessness, we mean the historical absence of the woman writer's text: the absence of a specifically female position on major issues such as slavery, colonialism, decolonization, women's rights and more direct social and cultural is-

4. Charles H. Rowell, "An Interview with Olive Senior," Callaloo 11 (Summer 1988), 485.

5. Carole Boyce Davies, "Writing Home: Gender and Heritage in the Works of AfroCaribbean/American Women Writers," in Out of the Kumbla: Caribbean Women and Literature, ed. Carole Boyce Davies and Elaine Savory Fido (Trenton, N.J.: Africa World Press, 1990), p. 59.

6. Sylvia Wynter, "Afterword," in Davies and Fido, Out of the Kumbla, pp. 361-62. 


\section{WRITING IN LIMBO}

sues. By voicelessness we also mean silence: the inability to express a position in the language of the "master" as well as the textual construction of woman as silent. Voicelessness also denotes articulation that goes unheard. ${ }^{7}$

Paradoxically, the Caribbean women writers' consciousness and ultimate reversion of voicelessness into sound and words have led to the revision of Caribbean modernist discourse in two respects: First, silence arises from what we have called the confinement of women to the private space, which is denied the value and resonance of public discourse articulated in borrowed European forms such as the novel and the essay. But in the same private spaces that were supposed to denote silence, Caribbean women writers have nurtured a language that, in the words of Olive Senior, "personalizes the socio-political issues": now the individual life becomes the primary focus "so all experience tends to be filtered through a particular consciousness" struggling against the pull and push of history. ${ }^{8}$ Second, amid the linguistic struggle between Prospero and Caliban, the language of the folk in particular and popular culture in general has been inserted as a third term that challenges and deconstructs the claims of both colonialism and male-centered nationalism.

A vivid example of how this third discourse functions can be found in one of the most memorable scenes in Merle Hodge's Crick Crack, Monkey. The author presents us with a symbolic confrontation between North American modernity (as articulated by Manhatt' $n$ ) and the Afro-Caribbean vernacular:

Manhatt'n was an individual who at some obscure date had 'goneaway.' Some of the boys said he'd only been to Curacao where he'd got a job for a few months; one section of opinion had it that he merely worked down on the Base for a few weeks. Manhatt'n himself gave it out that he'd been up Stateside, fellers, up Amurraca-side-for he always spoke with his mouth screwed to one side and all the words coming out of his nose. When the fellows were in a tolerant mood they would let Manhatt'n tell of his encounter with the sheriff in Dodge City and how he outdrew him; or of the blonde chick in Manhattan who wouldn't leave him alone, kept coming to his apartment when there was this red-head thing he was working at (Martinis, yer know, and a lil'

7. Carole Boyce Davies and Elaine Savory Fido, "Introduction:Women and Literature in the Caribbean: An Overview," in Out of the Kumbla, p. 1.

8. Rowell, p. 485 . 
caviar on the side). And when the fellows screamed with laughter Manhatt'n looked imbecilically happy. But when one day someone maliciously murmured 'Crick-crack!' at the end of one of these accounts in perfect Western drawl, Manhatt'n in his rage forgot to screw his mouth to one side before starting to speak. ${ }^{9}$

Manhatt'n lives out the fantasy of colonial and neocolonial modernism-the desire to be European or American-but this fantasy is constricted by the realities of the folk culture of which the "Crickcrack" narrative formula is an important subversive agent. ("Crickcrack" is the opening formula or refrain for many folktales in the AfroCaribbean tradition; it is intended to remind listeners, especially children, that the story is imaginary.) And although values in this "modern" world are primarily masculine and women are instruments of imaginary exchange and verbal degradation, women still manage to subjectify themselves in their stories and produce narratives that not only celebrate their lives and ancestry, but also deflate "the makebelieve value system" of the colonizer. ${ }^{10}$ As the women of the Sistren collective have asserted, the function of narrative in the patois, the displaced parole, is to lift the veil of silence surrounding the lives of Caribbean women and hence break the power of the oppressor; writing after colonialism demands a literary form and language that allow the narrators to confront, rather than escape, their material objectification in the language of the colonizer, as a precondition for subjectivity. ${ }^{11}$

The basic premise in the works I examine in this chapter-Merle Hodge's Crick Crack, Monkey and Zee Edgell's Beka Lamb-is that the unveiling of the lives of Caribbean women not only recenters them in history as custodians of an oral tradition, but also functions as an indicator of sources of domination that might have been lost or repressed in both the colonial text and male-dominated nationalist discourse. Indeed, according to Hodge, colonial education, by presenting the lived experiences of the Caribbean people as invalid, negated the very subjectivity of the colonized by taking them away from their "own reality": "We never saw ourselves in a book, so we didn't exist in

9. Merle Hodge, Crick Crack, Monkey (London: Heinemann, 1981), p. 7. Further references are in the text.

10. Kathleen M. Balutansky, "We Are All Activists: An Interview with Merle Hodge," Callaloo 12 (Fall 1989), 657.

11. See Sistren with Honor Ford-Smith, Lionheart Gal: Life Stories of Jamaican Women (Toronto: Sister Vision, 1987), pp. 1-19. 
a kind of way and our culture and our environment, our climate, the plants around us did not seem real, did not seem to be of any importance-we overlooked them entirely. The real world was what was in books." 12 In a situation in which existence and significance are defined by the texts we write and read, as Hodge seems to suggest here, then the absence of female texts in the Caribbean canon meant that political independence had not restored speech to the Caribbean female subject, an important producer of West Indian culture. The culture of West Indian women, argues Hodge, hadn't "been given a name and it didn't get recognized as a culture." 13 Even in the period after independence, according to Honor Ford-Smith, there exists among the women of the Caribbean "a need for a naming of experience and a need for communal support in that process. In the past silence has surrounded this experience." 14

Narratives like those of the Sistren collective are indeed some of the most important ways Caribbean women devise what Pat Ellis aptly calls "strategies to overcome the obstacles that threaten to curtail their freedom." 15 And if the doctrine of modernity transfers the authority of power and utterance in the Caribbean to the black male, then a feminist renaming of experience implies the revision of modernism, even the outright rejection of its totalizing tendencies; by positing gender differences as a site for representing and reconstructing new identities (in narrative and semiotic terms), Caribbean women writers are establishing what a leading feminist scholar of modernism has called "the conditions of existence of those subjects who are muted, elided, or unrepresentable in dominant discourse."16

The two texts I have selected to illustrate this point deal with the same colonial condition discussed in previous chapters, but they have a different formal and thematic emphasis; they also present a different structural relationship among subjects, dominant discourses, and their situations of production. These texts posit the linguistic terrain as one of multiple struggles rather than a Manichaean relationship between self and other. Instead of striving to establish a dialogue be-

12. Quoted in A Handbook for Teaching Caribbean Literature, ed. David Dabydeen (London: Heinemann, 1988), p. 78.

13. Balutansky, p. 653.

14. Ford-Smith, p. 7.

15. Pat Ellis, "Introduction-An Overview of Women in Caribbean Society," in Women of the Caribbean, ed. Pat Ellis (London: Zed, 1986), p. 1.

16. Teresa de Lauretis, "Feminist Studies/Critical Studies: Issues, Terms, and Contexts," in Feminist Studies/Critical Studies, ed. Teresa de Lauretis (Bloomington: Indiana University Press, 1986), p. 9. 
tween the colonizer and the colonized as a means of revising the status of the colonial subject in the colonizing structure, the priority of these texts is the despoilment of what Michelle Cliff calls the master's "cultural soup" - "mixing in the forms taught us by the oppressor, undermining his language and co-opting his style, and turning it to our purpose."17 Whereas earlier generations of Caribbean writers sought ways of appropriating and nationalizing European forms of representation-hence Césaire's indebtedness to surrealism or Lamming's affinity with high modernism-both Hodge and Edgell, writing after colonialism, are as much indebted to their Caribbean precursors as they are to the colonial text. They reverse and revise both the colonial and black male texts even as they try to validate the oral tradition. Rejecting the common notion of a subject whose identity is defined and fixed by the dominant patriarchal culture, Hodge and Edgell posit a self that is defined by ideological ambiguity and a self-contradictory identity.

\section{Writing the Individual Life: Crick Crack, Monkey}

Crick Crack, Monkey was the first major novel by a Caribbean woman-in the period after independence-in which the writer assumed the consciousness of her subject and gave it expression, hence using "autobiography" as a textual space for exploring the effects of colonialism on the budding Caribbean national culture. ${ }^{18}$ Hodge's strategy in this book was not to concentrate on the evolution of a public consciousness in her main subject, Tee, but to foreground questions of difference and the quest for a voice in a social context that denied expression to the colonized self and hence cut it off from the liberating forms of popular culture and the oral tradition in the Caribbean. For Hodge, this emphasis on voice as a precondition for black subjectivity in a colonial situation was necessitated by both ideology and technique. First of all, in the plantation societies of the Caribbean, the voices of the oppressed and dominated slaves and indentured laborers survived against the modes of silence engendered by the master class. For these slaves and laborers, the preservation and inscription of a distinctive voice came to signify the site of their own

17. Michelle Cliff, "A Journey into Speech," in The Land of Look Behind: Prose and Poetry (Ithaca, N.Y.: Firebrand Books, 1985), p. 1.

18. Balutansky, p. 654 . 
cultural difference. Second, the voice was variously an instrument of struggle against domination and a repository of African values in a world in which the slaves' traditions were denigrated and their selfhood repressed. ${ }^{19}$ In narrative terms, the recovery of voice would become one way through which unspoken and repressed experiences could be represented.

In Merle Hodge's novel, then, the voice is a synecdoche of the unwritten culture of the colonized, the culture of Aunt Tantie and Ma; and its privileging in the text signifies an epistemological shift from the hegemony of written forms (which, as we saw in previous chapters, have been a source of anxiety for colonized peoples) to an Africanderived orality. At the same time, the negation of the spoken utterance through education and assimilation functions as a mark of deep alienation. Within this tenuous relationship between the oral and the written, as Tee discovers when she opens her retrospective view of her childhood at the beginning of Crick Crack, the past cannot be narrated without a cognizance of the contradictory voices that defined itrepressive voices coexisting with liberating ones. The figure of the voice is shown to be both central to the narrator's conception of her childhood and a paradigm that defines the context in which her multiple selves were produced. Indeed, at the opening of the novel, an ambiguous moment in which the birth of a new baby is superseded by the death of its mother, the world appears to Tee merely as a relationship of voices: "a voice like high-heels and stocking," "an old voice. . wailing," "some quavery voices," "a grumble of men's voices" (p. 1). The girl's subsequent alienation in the colonial world of Aunt Beatrice and the school is already prefigured by her inability to identify with any of these fetishized voices.

In addition, Tee's alienation as a narrating subject is obvious in the way her authority of representation is propped up and denied at the same time. For example, at the opening of the narrative, the narrator is not placed in the position of innocence and the absence of consciousness which is common in the Caribbean bildungsroman. At the beginning of the novel, Tee, along with her brother, has placed herself on a physical and narrative pedestal ("We had posted ourselves at the front window, standing on a chair" [p. 1]) from which she can represent her

19. Edward Kamau Brathwaite, History of the Voice: The Development of National Language in Anglophone Caribbean Poetry (London: New Beacon Books, 1984), and Edouard Glissant, Caribbean Discourse: Selected Essays, trans. J. Michael Dash (Charlottesville: University Press of Virginia, 1989), pp. 120-33. 
own experience with ostensible authority, controlling the reader's response to her social context. On closer examination, however, the reader discovers that what the girl represents is not her unique "reading" of phenomena, but her reproduction of the views and opinions of adult figures. Even what appears to be the narrator's clear perception of things is quickly proven to be hazy and ill-defined (pp. 2-3). Because the reader already knows that Tee's mother and the new baby are dead, and that her father has left the country, the narrator's limited knowledge is obvious in her conclusion that Papa "had gone to see whether he could find Mammy and the baby" (p. 3).

Hodge's narrative thus develops along what appear to be contradictory lines: the subject is privileged in the discourse, but this privilege is undercut by her function as the reporter of others' speech, or by her limited knowledge and perspective. This is an important strategy for showing how the subject develops in multiple and contradictory ways and for indicating the extent to which a unique sense of self is often produced by a painful struggle with the discourse of others. In this novel, we have moved away from trying to invent a new language of self to a recognition of Bakhtin's famous assertion that "language, for the individual consciousness, lies on the borderline between oneself and the other. The World in language is half someone else's." 20 Tee tries to constitute herself by striving for the fragmented languages of other people; but even as she reproduces other people's words and views, she is frantically seeking to institute the integrity of her voice and her privileged position as an observer and narrator. In other words, against her limited authority and truncated mastery of language, she still struggles to express things "otherwise," to endow received discourse with what Bakhtin would call the subject's "semantic and expressive intention." 21

Thus while her mother lies dying, Tee, who is only aware of the original reason for the mother's hospitalization (the birth of a baby), sits watching at the window, "struggling to keep my eyes open," her words expressing her now belated expressive intention and expectation: "There were fewer people going past now, so that I all but fell asleep between each set of footsteps. But I always revived to see if it

20. M. M. Bakhtin, The Dialogic Imagination: Four Essays, ed. Michael Holquist, trans. Caryl Emerson and Michael Holquist (Austin: University of Texas Press, 1981), p. 293.

21. Mikhail Bakhtin, "Discourse Typology in Prose," in Readings in Russian Poetics: Formalist and Structuralist Views, ed. Ladislav Matejka and Krystyna Pomorska (Cambridge: MIT Press, 1971), p. 190. 
was them, and if not to shout 'We gettin a baby!' to whoever it was"' (p. 2). And yet her attempt to evoke a narrative authority built on her position as an observer-that is, an eyewitness account-is immediately shown to be seriously flawed because she is not privy to the knowledge of death and suffering which, at this point in the story, is shared by the adults. At this juncture Tee's voice and perspective are overwhelmed by a multiplicity of adult voices that are disconcerting because they are totally estranged from their speakers. Now her own semantic and expressive intentions become secondary.

The result is further ambiguity in Hodge's narrative strategies: to the extent that the adult Tee is the narrator of this story, her position in the narrative is one of authority and control; but because young Tee is also the subject of this narrative, the fear and confusion of her childhood experiences can only be apprehended if her voice is contrasted with other voices. More important, the author rejects the kind of objectified descriptions we saw in our discussion of Lamming's early novels which might mediate the worlds of the juvenile subject and the adult narrator. Instead of evoking a narrative detached from speakers and narrators, Hodge presents us with a self at odds with the language in which it hopes to subjectify itself; within the confines of the novel, Tee's confusion and ambivalent relationship to her hybrid culture are paramount to any enlightenment and resolutions which the narrator might have arrived at as an adult. As Tee's voice is overwhelmed by adult voices, her subjectivity is shown to be more than an effect of her reality; rather, experience here is shown to be an effect of the character's attempt to create an image for herself outside conflicting social codes. Alternatively, self-perception becomes a projection of her fears and desires.

An important example of this kind of projection is apparent quite early in the novel when Tee is brought forward to pay her final respects to her dead mother:

The house was still full of people and there were flowers in thick bunches that didn't look like flowers at all but like a bristly covering for some sinister animal sleeping underneath; there was a shiny thing in a corner that I was afraid to look at and then an old woman took my hand and led me towards the corner and I grasped her hand tightly and shut my eyes and suddenly I was being lifted into the air and opening my eyes in alarm saw that I was passing over the shiny thing half-smothered by ugly still stuck-together flowers and then I landed into the shaky 
arms of another old lady on the other side; and then they picked Toddan and he screamed and kicked, so that they nearly dropped him with fright. [P. 3]

This paragraph is an excellent example of the kind of ambivalence that characterizes Crick Crack, Monkey. A narrative strategy of reversal is at work here. As we well know, the long complex sentence is traditionally a mark of the narrator's sophistication and mastery of form and situation. In this context, however, the long sentence foregrounds the child's confusion, especially her inability to create significance and to make sense of the solemn occasion-her mother's wake-which appears to her as surreal. The narrative situation becomes more complicated when we try to identify the speaking voice-the narrator or the character? The impressions seem to be those of young Tee, but the semantic situation is that of the adult Tee who retrospectively narrates her childhood story.

The above narrative situation is an example of what Roy Narinesingh, in his introduction to the novel, calls a meeting point where the child's and adult's visions "are made to coalesce" (p. vii). But to understand Tee's struggle to inscribe herself using the language of others, or to overcome her odd relationship to the language(s) that constitute her, we must also be cognizant of the splitting of her voice into what Bakhtin, in his theoretical studies of discourse in fiction, calls "two speech acts . . two entirely separate and autonomous voices." 22 We must be sensitive to the dual voices that determine the nature of narration in the text and Tee's self-representation-the voice of the child caught in conflicting linguistic situations, and the voice of the sophisticated narrator trying to establish her individual language after colonialism and exile.

There is still greater tension in the novel between what we may call "objective reality" - the unmediated, non-projected experience-and the subject's self-representation in images and spectacles, what Hodge would call the fantasies that define the colonial situation. ${ }^{23}$ For Tee, the self has the power to put the primary claims of experience into question, for it is only when the self has recreated reality in its own image, or evoked that reality as a projection of its desires, that selfrepresentation (and hence narration) become possible:

22. Bakhtin, "Discourse Typology," p. 190.

23. Balutansky, p. 657 . 
At the shed there was usually a fringe of children hanging about, and they let us shake the chac chac; there were some little boys who were regular pan-men and who even got to beat a pan on the road at Carnival. The players felt about idly and aimlessly on their pans for a long spell until without one noticing the sounds had converged into order. So close to the band that the bass-pans thudded through your belly, and the iron-section with the sounds crashing out from the touch of the tiny stick on the anonymous piece of engine entrails was your teeth clashing together in time with the beat. [P. 6]

The passage begins with a general description of the steel band shed, but as it progresses, we notice how the dichotomy between subject and object is narrowed; the narrator/character internalizes the objects (the bass-pans thud in her belly) and eventually merges the external with the internal so that at the end of the quotation she cannot tell the difference between the sounds from the iron-section and the clashing of her teeth. In essence, experience has value insofar as it is projected as a spectacle that the self itself has created. External reality is populated with the speaker's intention. ${ }^{24}$

There is another sense in which the above shift from an "objective" to a "subjective" form of representation brings out the ambivalence that characterizes, indeed produces Tee, as a colonial subject: the author needs to maintain a disjunction between Tee's functions as a narrator and as a character, and this necessitates not only the doubling of the self in language but also its alienation in the very strategies it develops to represent its doubleness. For if Tee were just to tell her story from the (ostensibly) non-problematic perspective of a child (an interesting comparison is Michael Anthony's The Year in San Fernando), the author might succeed in maintaining the integrity of the narrating self, but this unity could lead to the negation of her primary thematic concern-the alienation of this subject through her induction in "a make-believe value system." 25 On the other hand, if she were to narrate this story from the vantage point of the adult, then the representation of the subject's alienation could only be achieved through the erasure of the important illusion of integrity and unity we associate with the childhood narrator. Thus, although Hodge's goal is to express the theme of alienation, she operates from the premise that childhood holds the utopian possibility that Tee can exist, to quote Marjorie

24. Bakhtin, "Discourse Typology," p. 190.

25. Balutansky, p. 657. 
Thorpe, "in complete harmony with her environment."26 Furthermore, to understand the conditions in which the character becomes alienated in her inherited language and value system, we must also be in a position to read the gap that separates childhood from adulthood: as a character, Tee becomes alienated almost without her knowledge and consent; as an adult narrator, she posits self-representation in dominant discourse as a form of alienation which she has mastered through narration.

In his introduction to the novel, Narinesingh argues that the reader of Hodge's text is "made to share in the diversity and richness of Tee's experience without being able to discern at times where the child's voice with a child's perception of things slides into the adult voice and vision of the omniscient author" (p. vii). Now, while it is true that there are instances when the juvenile and adult visions seem indistinguishable, a more attentive reading of the text will surely highlight the differences between these two voices or call attention to their paradoxical relationship. If Hodge's intention is to expose the illusionary nature of Tee's desire for assimilation by highlighting the gap between her innocent (childhood) belief in the efficacy of the colonial system and her later (adult) troubled relationship with this system, the narrative is attuned to the divisions and separations the child goes through in her struggle to become the "other." For the narrating subject selfrepresentation often calls attention to the gap that separates experience (scenes of childhood) and the moment of narration (adult selfconsciousness).

Nowhere is this process more apparent than in those instances where obviously juvenile acts are represented in complex language and elaborate syntactical structures. In the following example, young Tee and her brother are prancing around with "Uncle" Mickey, but the description of this scene seems to suggest a more involved act:

The rest of the time we were strutting in his shadow, off to raid the Estate or down to the Savannah to fly our kites that he made us; or it was the long walk with the sun all around and stinging and blurryness rising from the road and the smell of asphalt, and the road soft under your toes and the grass at the sides no cooler and just when it was getting too

26. Marjorie Thorpe, "The Problem of Cultural Identification in Crick Crack, Monkey," Savacou 13 (1977), 32. See also Leota S. Lawrence, "Women in Caribbean Literature: The African Presence," Phylon 44 (March 1983), 1-11; and "Merle Hodge," in Fifty Caribbean Writers: A Bio-Bibliographical Critical Sourcebook, ed. Daryl Cumber Dance (Westport, Conn.: Greenwood Press, 1986), pp. 224-28. 
much we'd turn off the road and plunge between the bushes and down the precipitous path to the water. [P. 6]

Here, the narrated experiences belong to childhood, but the language is that of the adult narrator. There is thus a clear disjunction between experience and language which, in turn, signifies the temporal shift from a world in which the child's life was aimless to a time when she has acquired the language to turn such aimlessness into art. What this shift adds up to, everything else aside, is that there is no authentic subject before its representation in language; the pleasure of writing is inherent in the search for a language that will recover the fragments of a past life and turn it into a spectacle in which the narrator can "read" herself. After all, before the writing of Crick Crack, Monkey, who was Tee but the projection of other people's desires and intentions-Aunt Tantie, Ma, Beatrice, the colonial school?

The value of the juvenile perspective lies precisely in its capacity to show how Tee was colonized by the utterances of other subjects. The word monkey in the title of the book-a title that comes from the opening refrain in Caribbean folk narratives-has "all the associations of aping and imitation," as Hodge says, and is intended to call attention to the inauthenticity of Tee's adopted colonial world. ${ }^{27}$ As a result, a return to childhood does not establish a metaphorical relationship between the child and her landscape; what she hears, and often appropriates, is the "disembodied voice" of another. Consider this example: "Women going past walked a gauntlet of commentary on their anatomy and deportment. And for Mrs Hinds in particular they had no mercy. Like any proper lady (it seemed to me) she had a high, stiff, bottom and spectacles and stockings" (p. 7). Here we have the narrator not only representing the child's perspective on the boys' comments on Mrs. Hinds, but also using a parenthesis to make a distinction between how things seemed to Tee then and her superior knowledge now. Given the boys' commentary, Tee's juvenile view, and the narrator's qualifier, can we ever identify an original experience? My contention is that the loss of an original (childhood) experience-a loss that becomes more and more apparent as Tee moves away from the "organic" worlds of Tantie and Ma and enters Beatrice's colonial orbit-is what generates Hodge's "autobiographical" text. ${ }^{28}$

27. Balutansky, p. 657 .

28. See Françoise Lionnet, Autobiographical Voices: Race, Gender, Self-Portraiture (Ithaca: Cornell University Press, 1989), p. 6. I concur with Lionnet's important assertion that the "auto- 
Moreover, Tee's creative power seems to derive from her knowledge of the gap that separates her past and present images. Because the division of the subject-its splitting into a character and narratorand its lack of originality are results of the experience of childhood under colonialism, we cannot resort to this same experience as the source of an innocent, unalienated image of selfhood. As Michal Ginsburg observes in a study of Flaubert, who often resorted to this kind of divided self-representation, "From the moment there is memory, or desire, or language . . . from the very moment there is a self, the self is divided from itself, doubled and alienated from itself, and this division and difference are experienced as a loss, but as a loss that has already occurred and hence cannot be either avoided or made good." 29 In the circumstances, the question raised by the "autobiographical" narrative does not concern how alienation can be overcome, but how it comes about, and how it can be manipulated to create a new self in language and a new consciousness of self.

In an important study of subjectivity and language, Emile Benveniste has insisted that "consciousness of self is only possible if it is experienced by contrast." 30 For the colonized or marginalized self, this contrast is negative and oppositional: the self defines itself by being at odds with the given or imposed language, by struggling against the hegemonic voices that stifle its utterances. Similarly, the ideology of the self in Crick Crack is dependent on the presence or absence of Tee's utterances, measured against the utterances of others. At the beginning of the novel, when Tee tries to announce the inevitable birth of her mother's baby even as the mother lies dying, the contrary perspectives (those of adults, the messengers of death) are apprehended through voices that are unreal and dead; indeed, one voice (that of Aunt Beatrice, it turns out) has acquired a life of its own and is perceived as "the high-heels and stockings voice" (p. 2). Furthermore, each character in the novel, and each social class or caste, is defined by, and associated with, a particular speech community: Tantie speaks the

biographical theme" is connected to "diverse language systems" and culturally distinct frames of reference: "The space of writing in which these frames intersect positions the writing subject at the confluence of complex and sometimes conflicting creative impulses, which complicate both the writer's and the implied reader's relations in (and to) the text under scrutiny" (pp. 21-22).

29. Michal Peled Ginsburg, Flaubert Writing: A Study in Narrative Strategies (Stanford, Calif.: Stanford University Press, 1986), p. 32.

30. Emile Benveniste, Problems in General Linguistics (Coral Gables, Fla.: University of Miami Press, 1977), p. 224. 
creole version of the English language (the patois that, by doing "violence" to established speech, has acquired autonomy and identity); Ma's language reflects her ancient African and slave roots; Aunt Beatrice's utterances reflect her middle class, colonial image. It is against, or in relation to, these language forms (langue) that the subject must institute its individual utterance (parole).

But before the subject can fashion its own language, it must deliberate on the already given language. Thus in the course of her narrative Tee moves from one speech community to another without adopting the language of any of them into her consciousness: with the boys at the bridge, she shares the pseudo-cowboy language of Manhatt'n and his gang (p. 6); with Ma, she immerses herself in the language of the folk (p. 13); and at Mrs. Hinds's school, she begins to speak the formal language of the "Big-school" (p. 39). It must be emphasized, however, that at no stage does she speak any of these languages solely or rebel against them completely; rather, her identity is constructed by and within these speech or language systems. She belongs to all of them, but to none; in reality, she is consumed and confused by all of them. For this reason, what appeared at the beginning of the novel to be her narrative vantage point, a position of mastery and insight, is an adult position that conceals the uncertainty of the little girl. Similarly, her apparent security in the world of Tantie and Ma conceals, as does her later involvement with Beatrice's middle class culture, the state of anxiety and unbelonging she lives in.

My argument here runs contrary to Thorpe's influential reading of Crick Crack, where she casts the novel in a structural opposition in which Tantie's creole world represents "belonging and security" while Beatrice's colonial world stands for "alienation and displacement."31 Admittedly, these binary oppositions can be sustained if we approach the text from the perspective of Tee the narrator, who after her exile in Europe is presumably nostalgic and appreciative of the creole world from which she has been displaced by the colonial culture. But from the perspective of Tee the child, there is a strong ambivalence toward oppositions such as colonial/creole, Beatrice/Tantie; in neither of these worlds can she posit herself as a subject. In Tantie's world Tee echoes and repeats her aunt's language and views (p. 12); after she has lived with Beatrice for some time, her utterances now reflect the language and ideology of the colonized bourgeoisie (p. 85). In neither of these 
cultural universes can the child appropriate a language to designate herself as a subject which is not the effect of the other's language system; she cannot choose one entity as a way of overcoming her alienation. Nor can she return to Ma's world, which may represent the Caribbean cultural base but is inaccessible to the girl, not only because of the old woman's amnesia (she cannot remember her original name) but also because this peasant culture is marginalized in the colonial political economy.

So the value of Hodge's text does not lie in any possible resolution to the cultural dichotomies we have discussed so far. As Hodge has observed, Tee's enlightenment does not happen within the confines of the novel; her experiences only foreground her state of ambivalence and "unsatisfactory imitation." 32 The value of the novel hence lies in the author's capacity to sustain both the creole and colonial cultures as opposed sites of cultural production which the "modern" Caribbean subject cannot reconcile or transcend entirely. This cultural and linguistic opposition is embedded in the economic systems of the island (the world of the creole is one of peasant production while that of the colonial middle class is professional); but it is also reflected in a semiological opposition between the spoken and the written, between carnival and the school.

The power of orality is apparent in Tantie's mastery of creole speech and Ma's enchanted world of African mythology. Tee certainly feels at home in this world-indeed she celebrates it-but she is also aware of its incompleteness, of its marginalization in the modern economy. Her desire is hence for the scriptural universe of the colonial school which promises power and authority:

I looked forward to school. I looked forward to the day when I could pass my hands swiftly from side to side on a blank piece of paper leaving meaningful marks in its wake; to staring nonchalantly into a book until I turned over the page, a gesture pregnant with importance for it indicated that one had not merely been staring, but that that most esoteric of processes had been taking place whereby the paper had yielded up something or other as a result of having been stared at. [P. 20]

Thus the power of the school is clearly linked to writing; in turn, writing is posited as both a mythological practice (an "esoteric process") and a form of empowerment (the paper yields knowledge,

32. Balutansky, p. 654 . 
obviously a kind of power). In retrospect, however, literacy is a form of mastery achieved at the expense of the self which, as we have already seen, becomes alienated in the modes of representation which were supposed to empower it: "My reading career also began with A for Apple, the exotic fruit that made its brief appearance at Christmas time, and pursued through my Caribbean Reader Primer One the fortunes of two English children known as Jim and Jill, or it might have been Tim and Mary" (p. 25). When she was illiterate, Tee was mystified by the esoteric nature of written language; now an ironic narrator has developed knowledge about her previous mystification. ${ }^{33}$ She now knows that mastery of the colonial text does not lead to what Vévé Clarke has aptly called "diaspora literacy" - "the ability to read and comprehend the discourses of Africa, Afro-America and the Caribbean from an informed, indigenous perspective." 34

And yet alienation from the diasporic universe is a precondition for the character's ascendancy into the colonial situation. Indeed, when Tantie allows Beatrice to introduce Tee into this alienating world after the "exhibition exam," she seems to confirm the girl's suspicion that the creole world is one of collective economic and political marginality and that only accession into the language and discourse of colonialism empowers (pp. 61, 68). As a result, Tee's cultural alienation is built around a crucial chiasmic reversal: the tangible reality of the creole culture, a reality that pulsates in its myths, its speech patterns, and its carnival (what Beatrice contemptuously refers to as "ordinary") is dismissed as an unreal construct, while the fictions promoted by the colonial textbook are now adopted as the "real" Caribbean referent:

Books transported you always into the familiar solidity of chimneys and apple trees, the enviable normality of real Girls and Boys who went a-sleighing and built snowmen, ate potatoes, not rice, went about in socks and shoes from morning until night and called things by their proper names. . . Books transported you into Reality and Rightness, which were to be found abroad. [P. 61]

The colonial library, represented here by the book van (which Tee awaits every Saturday "with the greatest of impatience"), is a mirage

33. I have borrowed this formulation from Paul de Man. See "The Rhetoric of Temporality," in Blindness and Insight: Essays in the Rhetoric of Contemporary Criticism (Minneapolis: University of Minnesota Press, 1983), p. 214.

34. Vévé A. Clark, "Developing Diaspora Literary: Allusion in Maryse Condé's Heremakhonon," in Davies and Fido, Out of the Kumbla, p. 304. 
that has become a tangible reality in the girl's imagination and desire. The world of the "ordinary" is denied referentiality because, as Thorpe notes, it is the exact opposite of, indeed contradicts, "the values of the former colonial masters" and hence undermines the realm of colonial desire. ${ }^{35}$

In this context, in an attempt to deal with her dualities and crisis of identity, Tee begins to apprehend herself as the colonial "other": she invents a double, a mirror image of herself who is, nevertheless, white and thoroughly colonial, a subject so ideal that she doesn't have to negotiate the dangerous chasm between the contradictory creole and colonial worlds:

Thus it was that I fashioned Helen, my double. She was my age and height. She spent the summer holidays at the sea-side with her aunt and uncle who had a delightful orchard with apple trees and pear trees in which sang chaffinches and blue tits, and where one could wander on terms of the closest familiarity with cowslips and honeysuckle. . . . Helen entered and ousted all the other characters in the unending serial that I had been spinning for Toddan and Doolarie from time immemorial. [P. 62]

In a world where the real is reversed into its contrary and the unreal becomes the object of 'desire, Helen is more than a double; she has usurped Tee's self. The spectacle in the mirror is the real person, and the real person is the unreal image in the mirror: "She was the Proper Me. And me, I was her shadow hovering about in incompleteness" (p. 62).

If we adopt the Lacanian notion of the "mirror stage," we can argue that the colonial subject has recognized itself in an ideal $I$, but this form of identification is also a misrecognition because the externalized image is achieved only in return for self-alienation. ${ }^{36}$ Moreover, the subject can never assimilate this idealized image because it has no existence except in the imaginary. Yet the mirror image is, nevertheless, the object in relation to which the subject defines herself. The radical dualities that identify this subject and its entrapment in the imaginary, argues Kaja Silverman in another context, are "a consequence of the irreducible distance which separates the subject from its ideal reflection, [and] it loves the coherent identity which the mirror

35. Thorpe, p. 34 .

36. Jacques Lacan, Ecrits: A Selection, trans. Alan Sheridan (New York: Norton, 1977), p. 2. 
provides. However, because the image remains external to it, it also hates that image." 37 Tee does not express any overt hate for Helen, but there is obvious recognition (from the narrator) that there were profound tensions between the two characters. This tension is clearly brought out in an important passage in the novel when the narrator explains the social and historical conditions that necessitated a double:

For doubleness, or this particular kind of doubleness, was a thing to be taken for granted. Why, the whole of life was like a piece of cloth with a rightside and a wrongside. Just as there was a way you spoke and a way you wrote, so there was the daily existence which you led, which of course amounted only to marking time and makeshift, for there was the Proper daily round, not necessarily more agreeable, simply the valid one, the course of which encompassed things like warming yourself before a fire and having tea at four o'clock; there were the human types who were your neighbours and guardians and playmates-but you were all marginal together, for there were the beings whose validity loomed at you at every book, every picture. [P. 62]

Tee is structured by a set of oppositions, none of which offers her true identity: her creole world is makeshift and marginal; her desired colonial universe is artificial. When she recognizes the sources of marginality and the nature of artifice, then she will outgrow Helen "in the way that a baby ceases to be taken up with his fingers and toes" (p. 62). As the adult narrator of her own experiences and subjectivity, Tee will not need such mediators; she will represent herself through writing.

In any case, if we look at the images and symbols that identify the ideal image, this time from the perspective of the narrator rather than the subject, we can see how the writer has used modes of representation which call attention to the arbitrariness of the colonial double and her world. In an ironic way, the coveted colonial world is signified by fetishes, such as old pictures. For example, Aunt Beatrice's only connection to the colonizer and conqueror-the entity that dominates her imaginary realm and represents her mirror image-is an old picture, that of "The White Ancestress, Elizabeth Carter": "The photograph was as faded as a photograph could manage to be, but Aunt Beatrice said that the minute Carol came into the world everybody could see that she resembled her, and so Carol's middle name was Elizabeth, as

37. Kaja Silverman, The Subject of Semiotics (New York: Oxford University Press, 1983), p. 158. 
my poor mother was named" (p. 81). And so a faded object becomes the justification for alienation, for distancing oneself from "those common raucous niggery people and all those coolies" (p. 86). But because these idealized images are unreal, they also highlight the failure of the colonial subject to expropriate the colonizer's discourse for a new national identity. This failure originates or is manifested in the question of language.

In his discussion of discourse in fiction, Bakhtin has noted the ways language is overdetermined by intentions exterior to the self that uses it: "Language is not a neutral medium that passes freely and easily into the private property of the speaker's intention; it is populated-overpopulated-with the intentions of others. Expropriating it, forcing it to submit to one's intentions and accents, is a difficult and complicated process." 38 Tee's struggle to populate other people's languages with her own intentions functions within the larger, problematic realm of anticolonial discourse in the independent period: what is the current status of the earlier nationalist (and hence male) belief that certain tenets of colonial modernity could be appropriated for the development of the new nation and in the fashioning of a narrative of national identity? The crisis of identity facing the child protagonist in her novel, asserts Hodge, is symbolic of the nascent Caribbean nations' quest for an integrated national culture. ${ }^{39}$

\section{Rewriting the National Allegory: Beka Lamb}

Inevitably, the awakening of the colonial subject to self-consciousness in Caribbean literature is closely connected to questions of nationalism and national identity. As the self struggles with its crisis of identity, so does the nation; as the nation strives for forms and styles of expressing itself, and yearns for a language in which to articulate what Benedict Anderson has aptly called its modalities, so does the subject seek its unique utterance. Notions of self and nation are indeed "artifacts of a particular kind." 40 But in Caribbean women's writing-as generally seems to be the case in women's literature in most of the socalled Third World - the relationship between self and nation is more

\footnotetext{
38. Bakhtin, The Dialogic Imagination, p. 294.

39. Balutansky, p. 653 .

40. Benedict Anderson, Imagined Communities: Reflections on the Origin and Spread of Nationalism (London: Verso, 1983), p. 13.
} 
complicated than the above exposition may suggest. In the first instance, as Jean Franco has recognized, the problem of national identity has often been presented as one of male identity, and it is often male writers "who debated its defects and psychoanalyzed the nation." If the doctrine of modernization is intended to map and encode "home territories and genealogies," women are excluded from the sites in which national culture is produced. 41

Still another issue is made more explicit in Zee Edgell's Beka Lamb: although the imagination of an autonomous Caribbean self demands the radical reconceptualization of its territorial and social spaces, these spaces are defined by linguistic ambivalence. Both the self and its community have to reinvent themselves using the language and cultural symbols borrowed from the colonizer, because only such a language and such symbols are seen as adequate for synthesizing the often antagonistic ethnic and class differences that define the new nation. Although individual and national identities need to harness such differences and ambivalences to subvert the colonial machine of domination and its neocolonial successor, the question of rewriting the allegory of the nation once the colonizer has departed still dominates Caribbean discourse. This problem is crucial in Caribbean literature written after independence because there is suspicion among many Caribbean writers and intellectuals that some of the nationalist discourse developed during the anticolonial struggle is populated by the intentions of others and hence carries within it those forces that retard the awakening of self-consciousness and hence national identity and "nationness." Moreover, there is the outstanding question of whether Caribbean cultural diversity hinders or promotes the development of national consciousness.

In Edgell's text, published shortly after Belize's independence, the devalorization of colonial modernism and its authority is achieved through an appeal to figures and tropes of difference and ambivalence. As they are represented in language and ideology, such figures express the kind of diversity which according to Glissant allows Caribbean peoples to repossess their historical spaces. In Glissant's words, "Diversity, which is neither chaos nor sterility, means the human spirit's striving for a cross-cultural relationship, without universalist transcendence. Diversity needs the presence of peoples, no longer as objects to be swallowed up, but with the intention of creating a new

41. Franco, p. 131. 
relationship. Sameness requires fixed Being, Diversity establishes becoming." 42 The colonial power fixes the colonized as objects of labor and/or appendages of the colonizing culture. Rewriting the Caribbean national allegory thus demands a narrative strategy that confronts the objects and historical forces blocking the desire for that diversity that establishes becoming. As a strategy of individual and national identity, ambivalence disperses the fixed sites of colonial cultural production; in semiotic terms, as Julia Kristeva says, it "implies the insertion of history (society) into a text and of this text into history." 43

Consider the function of ambivalence in the opening sentences of Beka Lamb: “On a warm November day Beka Lamb won an essay contest at St. Cecilia's Academy, situated not far from the front gate of His Majesty's Prison on Milpa Lane. It seemed to her family that overnight Beka changed from what her mother called a 'flat-rate Belize creole' into a person with 'high mind.' "44 This introduction appears to be constructed around a series of binary oppositions: the beginning of the novel is its end, the colonial school and prison are placed in contrast, and Beka's creole "past" is opposed to her new "high mind" (middle class) identity. On closer examination, however, the opposition between these entities cannot be easily sustained. For one thing, a novel that begins with its ending often promotes a moment of interpretation which is definite and conclusive; the reader is supposed to follow the incidents related in the flashback from the vantage point and certain knowledge denoted by narrative closure. But this is not the case in Beka Lamb: we are not certain that Beka, by winning the coveted essay contest, has initiated the decisive transformation of moral character and social class which her family and community expect. On the contrary, Beka's ostensible transformation is presented by the narrator as if it were merely the subjective (and possibly erroneous) assumption of her family - "It seemed to her family ..."-a mode of representation clearly intended to create doubts about the given significance of the essay contest and the colonial economy of meaning with which it is associated.

The very notion of a radical shift in Beka's character and position in the community is further undermined by the problematic expression

42. Glissant, p. 98.

43. Julia Kristeva, Desire in Language: A Semiotic Approach to Literature and Art, ed. Leon S. Roudiez, trans. Thomas Gora et al. (New York: Columbia University Press, 1980), p. 69.

44. Zee Edgell, Beka Lamb (London: Heinemann, 1982), p. 1. Further references are in the text. 
of temporality in the novel. We are told, on one hand, that "before time" (that is, in the past), Beka had no hope of winning the essay contest because "the prizes would go to bakras [whites], panias [mestizos] or expatriates" (p. 1). A new consciousness is hence dawning on Belize, and the creole majority is now being recognized as a powerful force. On the other hand, however, this "new" consciousness cannot be apprehended except in relation to the past. In fact, as we read the novel and retrace Beka's struggle to establish her identity within the social order of colonialism (represented by the school) and the as yet unrealized dream of national culture (expressed by her grandmother and other nationalists), we begin to realize that the essay contest is loaded with ironic implications. Initially promoted as the sign of historical transition-from past to present, creole to bakra, colony to nation-the essay instead draws our attention to the difficulties of forging new identities and expropriating colonial modernism and its discourse. The essay marks the gap between an unrealized identity and the realities of colonial domination and repression; it becomes a synecdoche of what is referred to euphemistically as "these hard times" (p. 3).

Like many of the other characters discussed in the previous pages, Beka Lamb casts her quest for a "new time" in the familiar terms of modernity enumerated at the beginning of this book. Modernismespecially as it is promoted by the school-is seen as the ability of the subject to be liberated from tradition and to evolve her own unique vision of life. Indeed, Beka's fantasy is to escape from both the world of "before time" (represented by her grandmother) and the vision of the damnation that, according to her Catholic teachers, awaits her at the end of her life. In this connection, Beka's moral and social strivings don't represent any significant form of self-engenderment; on the contrary, in making a "shift" from "the washing bowl underneath the house bottom to books in a classroom overlooking the Caribbean sea" (p. 2), she has to choose between two different forms of socialization, to try and fit into, or repeat, predetermined visions and ideologies. This repetition, then, frustrates the very quest for individuality which Beka thought she was involved in once she had won the essay contest. The essay may have earned her recognition both at home and in the school, but it also accentuates the tensions she feels as she is forced to choose between the values of her community and the agencies of colonialism. 
In a sense, Edgell places Beka in a state of limbo between an emerging national culture and the colonial situation. As the texts discussed in the previous chapters illustrate so well, this position in itself is not new or unique in Caribbean literature; what is unique about Beka Lamb, though, is Zee Edgell's ability to develop a tense dialectic between the subject on one hand, and her community and colonial society on the other hand, without falling back on the old and worn-out polarities of tradition and modernity. In this kind of dialectic of subject and community, as John Brenkman has noted in his study of the self-constituting power of the speaking subject in language, "the experience of the subject, who is constituted by and constituting through language, is lived within the struggle between the unrealized community and those social institutions which, deriving from the divisions of the community, shape the situations, interactions, and arrangements of everyday life." 45 Significantly, in Edgell's novel, the subject and her community mirror each other's anxieties.

These anxieties are expressed most vividly in Beka's dream at the beginning of chapter 2 of the novel. In the dream, "barefooted old men" have chained "off the bridge approaches, in front and behind" Beka, cutting her off:

It was too late. The bridge, shuddering beneath her feet, began turning slowly away from the show. Back and forth along the narrow aisle she ran, stopping again and again to shout and beat on the high wall separating the main traffic line from the pedestrian aisle. But the rattle and creak of machinery, and the noise from both sides of the creek, prevented the operators behind the wall from hearing her voice. [P. 6]

The dream, then, signifies Beka's anxiety at being displaced from her culture; she is cut off from her people by the bridge; a wall closes off alternative routes of escape; in the end, she is isolated and deformed: "She felt shrunken except for her head which had grown to the size of a large calabash" (p. 7). More important, this anxiety of selfhood is directly related to the community's fears about its own destiny as a nation, anxiety about Guatemala's long historical claims to Belize, and even about the country's capacity to survive as an independent economic entity because of its diminutive size. In effect, Beka's quest for a new image is subconsciously a collective undertaking, the kind of

45. John Brenkman, Culture and Domination (Ithaca: Cornell University Press, 1987), p. 174. 
undertaking which, to borrow Brenkman's terms, "unfolds within the effects and the struggles of the social community's divisions." 46

In many ways, nationalism and the national community are desired as the only sites in which the self can fully subjectify itself. At the same time, the unrealized-and hence desired-community is posited as an unknown terrain in which both the nation and the self might fail to find satisfaction or even survive. In Beka Lamb, the unrealized dreamthe imagined, independent Belize community—is not only fenced on all sides, but is also structured by historical ambivalences. Indeed, the mahogany tree, which is supposed to be the national symbol of Belize, functions in the novel as a displaced signifier:

In the brief sketch of the colony Beka had studied at school, there was a drawing of two black men, bare to the waist, standing on either side of the spreading branches of a mahogany tree. One held an axe, the other a saw. Beka had been told in history class, the year she failed first form, that the Latin words beneath the picture meant: "Under the shade we flourish." [P. 8]

The disjunctive relationship between Beka-and her communityand the symbol that is supposed to denote their communal desires is apparent here. First, the girl's knowledge of her national history is "sketchy," suggesting that the mahogany symbol is not sustained by a system of concrete knowledge; second, the national motto is in Latin, a dead language that is unintelligible to Beka. Later we are told that Beka had "never seen a mahogany tree in her life. . . . Moreover, Beka's dad was too impatient a man . . to subject himself to the uncertainties of the mahogany tree scattered fewer than ten to an acre out in the bush" (p. 8). In addition, there is a crucial ironic reversal of the national symbol in the above passage: the mahogany is unreal for many of the people of Belize, as unreal as the European flora and fauna that Beka reads about in books, or the roses her mother attempts to cultivate year after year-"roses like those she saw in magazines which arrived in the colony three months late from England" (p. 9). Consequently, the self cannot invest in a symbol that, strictly speaking, represents the colonizer's fantasy about what Belize should be, rather than what it is.

The metonymic function of the mahogany is mirrored in other displaced images that represent Belize city and its creole culture. For

46. Brenkman, p. 174 . 
example, we are informed that "in three centuries, miscegenation, like logwood, had produced all shades of black and brown, not grey or purple or violet, but certainly there were a few people in the town known as red ibos" (p. 11). But what value does the word miscegenation have in this context? The blending of races does not lead to the end of differences because shades have come to denote racial categories, and "each race held varying degrees of prejudice concerning the others" ( $p$. 12).

It is against this background of cultural ambivalence and shifting signifiers that Beka must constitute herself. She has three choices: she can develop a relationship with her country and its history and hence come to terms with her grandmother's vision of a new national community; she can adopt and reproduce the values of the colonizer and hence negate her communal identity; or she can reinvent herself and her own realities. In Edgell's narrative scheme, however, Beka cannot make any of these choices before she overcomes her fatal flaw-her habit of lying. This habit denotes more than a reluctance to tell the truth-it is part of Beka's drive to invent an alternative reality beyond the assimilative tendencies that repress selfhood. Thus Beka and her friend Toycie don't merely appropriate the legends of the country: "They never failed to make up stories about why the crippled British Baron had left his entire fortune to the country" (p. 13). Such "madeup" stories are strategies of subverting the truth of the already written, of conventionalized fashions of history. Beka's habit of lying is also part of the same process that leads her to construct her "world of fantasy" (p. 15); what her father would dismiss as "artificiality and sham" (p. 21) is her strategy of establishing her own position in the midst of conflicting social codes. In short, the dominant social field is subverted by the energies of the imagination.

Significantly, the imaginary allows Beka to hallow a space of selfconstitution somewhere between the creole community and the colonial tradition. Although she cannot choose between the colonial past and the modernist future in which the hopes and aspirations of Belize and its people will be fulfilled (as we have seen, the symbols of the emerging nation are already overdetermined by the colonizer and are hence compromised), she has the power, in the present moment of transition, to create her own normativity out of the ambiguous codes provided by her hybrid cultures. ${ }^{47} \mathrm{~A}$ remarkable example of how

47. I borrow the concept of normativity from Jürgen Habermas, The Philosophical Discourse of Modernity (Cambridge: MIT Press, 1987), p. 7. 
ambiguity leads to normativity is the man who wears his mask to evoke not his inner essence and cohesion, but his alienation. The masked man, we are told, is a creole who "compromised the daughter of a Carib man who had befriended him. Maskman could not marry the girl, though he loved her, without losing face in the creole community, whose members seldom married among the Caribs, although these two groups shared, in varying degrees, a common African ancestry" (pp. 31-32). Difference and division having proven to be stronger than a common ancestral heritage, "so it was said," a group of Carib people "in painted masks" entered the man's room and touched his face and neck "obeahing him so that these parts of his body became dotted with white speckles, leaving the rest of his body black" (p. 32). The man would hence seem to wear a mask to hide the unusual convergence of white dots and a black skin.

Nevertheless, the meaning of the mask, like many of the stories told about the masked man, is very indeterminate. Indeed, if the normative value of the African mask lies in its containment of what Gates calls "a coded, secret, hermetic world," and in its symbolization of what we could consider to be the inner essences of a race or culture, the masked figure in Beka Lamb plays a reversed role: he is a figure of transformation and ambivalence, and his presence in the novel calls attention to cultural indeterminacy in Belize. ${ }^{48}$ Moreover, the masked man foregrounds the paradoxical relationship between the plural cultures of Belize and their anxiety toward their ancestral African cultures. Rejected by both the creole and the Caribs, the masked man represents the pain of division, a pain Beka also shares as she is forced to reflect on the meaning of her given identities and her national "rights" (p. 37). In similar vein, Toycie finds it difficult to identify with her most valued possession - her guitar-which was made in Spain, an imperial power that is partly responsible for Belize's identity and political crisis: "Guatemala claims Belize from Britain through rights inherited from Spain, and Spain got rights from the Pope, and who are we going to get rights from?" (p. 36). In this historical record of treaties and rights, it appears that there is no place for Belize. But in trying to imagine a future autonomous community, the two girls feel they can harness their imagination to reclaim their national territory: thus, the

48. Henry Louis Gates, Jr., Figures in Black: Words, Signs, and the "Racial" Self (New York: Oxford University Press, 1987), p. 167. 
sign "made in Spain" is erased from the guitar and Toycie scrawls "Belize" instead, thereby inventing a community with which she can identify (p. 37).

What we witness in the above examples is the transformation of an individual fantasy (the need to socially possess a significant object) into what Deleuze and Guattari, writing about desire and identity in general, call the "revolutionary pole of group fantasy" - "the power to experience institutions themselves as mortal, to destroy them or change them according to the articulations of desire and the social field." 49 Still, the kind of imaginary power which allows the two girls to erase Spain and replace it with Belize is cast in an ambivalent mode. For even as nationalism spreads in the colony and things British are questioned and even discarded by some, the act of erasing the past also deprives Beka of one of the few certainties she had-the knowledge that she was a "British subject" (pp. 53-54). At the same time, old people like Granny Stackler-those "that remember things from the time before" (p. 62)-are dying and with them memories of an ancestral past. Clearly the characters are shaped by their consciousness of a past that can no longer be recovered and a present that is fast being displaced by an unknown future; this rapid change causes much confusion in the colony, prompting the community to reread a past they would have preferred to ignore. For this reason Beka construes her great-grandmother's wake as both a rite of passage and "a small lesson in community history" (p. 63). Whether this reflection on the past has any value is the cause of an interesting dispute between Beka's mother and grandmother: while the latter identifies with "the old ways" symbolized by the wake, the former is adamant in her belief that "the old ways will poison the new" (p. 66). Where, then, is the foundation of the future, of the "progress" desired if the national community is to be realized?

Like Hodge before her, Edgell adopts a narrative stance that complicates the question of value and identity after colonialism by abrogating the binary divisions (past/present, Carib/creole, etc.) that might make the colonial subjects' choices easy. In the process, both the self and its community are shown to be constructed around artificial ideals; they exist in the reality of the unreal, of fantasy and dream, of what the

49. Gilles Deleuze and Félix Guattari, Anti-Oedipus: Capitalism and Schizophrenia, trans. Robert Hurley et al. (Minneapolis: University of Minnesota Press, 1983), pp. 62-63. 
anthropologist Michael Taussig has brilliantly shown to be the space of "unconscious cultural formations of meaning." 50 In a telling example of this "unconscious" cultural formation, the children in the Catholic school gossip about the mixed racial origins of the local priest, Father Nuñez, and his mimicry of his European counterparts, but their discourse is predicated on a false notion of what is conventional and real:

These comments, overheard, perhaps misunderstood, no doubt misconstrued, formed the basis of the young people's attitudes toward Father Nunez. The majority of students in St. Cecilia's could not be expected, at their age, to perceive the underlying conflicts in Father Nuñez's personality. They had a romantic notion of how Belizeans ought to behave, and to them Father Nunez was hypocritical adopting the mannerisms, language, and style of living of his foreign counterparts-faults they, of course, would seldom be guilty of as adults. [P. 89]

The ironic twist at the end of the quote is right on the mark-the students have already been shown, as we have seen in the case of Beka, to be caught up in the same kind of cultural crisis and mimicry as Father Nuñez. Nevertheless, there is something remarkable about their dissociation from his "hypocritical adoption" of foreign mannerisms; for although the students are being assimilated into the colonial system in ways that closely parallel the priest's "lonely journey from Xaicotz to Rome" (p. 89), their discourse has initiated a theoretical subversion of the doctrine of assimilation. For them, adoption of foreign cultures is not an ideal but a problem. As Taussig would put it, this is a first step in the demythologization of history and reified representations; unlike Father Nuñez, who still believes in the efficacy of the imperial system of meanings, the students have developed a "hermeneutics of suspicion." 51

\section{The Question of Closure}

From Lamming's early novels to the two novels discussed in this chapter, the central texts of Caribbean modernism are dominated by a certain anxiety about endings which is also an anxiety about new cultural beginnings. At the end of In the Castle of My Skin, as he

50. Michael Taussig, Shamanism, Colonialism, and the Wild Man: A Study in Terror and Healing (Chicago: University of Chicago Press, 1986), p. 9.

51. Taussig, p. 10. 
prepares to leave Barbados for the journey that will inevitably lead him to Europe, the boy G observes that "the earth where I walked was a marvel of blackness and I knew in a sense more deep than simple departure I had said farewell, farewell to the land." 52 The sense of melancholy and loss which characterizes this passage also suggests a form of identity with the landscape being left behind, so that when the exiled colonials return, as they do in Césaire's Cahier or Lamming's Of Age and Innocence, their desire for the reclaimed space of the nation is defined by their previous sense of loss. Moreover, the problem of endings in narratives of national identity is of utmost significance because, as Jean Franco has asserted in relation to Mexican literature, "it is precisely the closure of the novel that is the place of ideological ambiguity." 53 This ambiguity is, of course, triggered by the incomplete nature of modernity, the limits of modernization, and the unfulfilled dreams of nationalism in the neocolonial period. For even after the achievement of national independence, complete autonomy evades many Caribbean countries; modernization entails still greater dependence on the "world economic system," while modernity (and postmodernity) are determined by the new mass media systems from the West. 54

Clearly independence has not resolved the problems of identity and national culture discussed in this book. Furthermore, by appropriating the infrastructure of colonial modernity, independence has complicated the process of narrative and social closure in the Caribbean text. For if the colonization of the Caribbean ushers in European modernity, then it is possible to argue that the Caribbean text seeks its autonomy by denigrating the colonial modernist project. But since official discourse in the neocolonial period still holds that the meaning and value of independence lie in the ability of the ex-colonial elite to sustain modernity, then a conflict of intentions between the politicians and writers seems inevitable. In other words, independence, by failing to resolve the question of identity and consciousness raised in the nationalist period, has complicated cultural formation in the islands; it

52. George Lamming, In the Castle of My Skin (New York: Schocken, 1983), pp. 297-98.

53. Franco, p. 132.

54. In an earlier period of Caribbean history, according to Lamming, the United States "existed for us as a dream, a kingdom of material possibilities accessible to all"; but America was also "the extreme example of Europe, stripped naked of all pretense about having a civilizing mission in the dark corners of the earth." See The Castle, pp. xiv-xv. In Hodge's view, the dominance of the American face of modernity is apparent in television. See Balutansky, $p$. 659. 
seems to have legitimized economic arrangements that are weighted in favor of the metropolitan centers, but it has failed to rationalize national consciousness, which has instead been reduced to what Fanon calls "an empty shell, a crude and fragile travesty of what it might have been." 55

In the circumstances, as Hodge has argued eloquently, the destiny of the new Caribbean nation is no longer clear or manifest: "It's much harder to point at the indicators of our domination, very difficult. When you tell people about the dangers of TV, they laugh. You can't tell people that TV or these new-style religions-the new fundamentalists-all are infiltrating us. It's hard to put that to people. So it is much more difficult to fight now." 56 In considering closure in both Crick Crack and Beka Lamb, it is important to keep in mind that although Hodge and Edgell are writing primarily about the transition from the colonial situation to national independence, they write with the privilege of at least ten years of the experiment in independence in the Caribbean region. It is not hence enough to read these novels in the traditional mode of the Caribbean bildungsroman; although they promise many of the formal and ideological features of this genre, and resemble other Caribbean novels of childhood in many respects, their endings are more troublesome.

In his introduction to Crick Crack, Narinesingh argues that Tee's departure from Trinidad is not a resolution to her crisis of identity because her inner dissonance will continue to plague her in England. He finds no comfort in her emigration: "Withdrawal from the situation by her emigration to England is not a morally affirmative position, for reconciliation can only be achieved by a mature revaluation of her condition. For Tee, personal synthesis and coherence are still to be achieved" (p. xiv). The reader's sense of ambivalence is exacerbated by the fact that Hodge has not presented us with a simple choice of ideological positions but with a series of equally tenable possibilities, placed in what Thorpe calls the "perplexing cultural situation" presented by Tee's departure for England at the end of the novel. Exile may seem to offer the girl a way out of the contradictory claims of the creole and colonial worlds, but it is not, Thorpe says, a "positive solution":

While the possibility exists that, in a foreign country, away from the pressures of her own society, Tee might in time be able to reconcile the

55. Fanon, p. 148.

56. Balutansky, p. 659. 
two cultural traditions which she has inherited, there is still the other possibility that, like the school-master Mr Hinds, her sojourn in the metropolis will merely aggravate her contempt for the local black creole culture, thus removing her permanently to the ranks of the culturally displaced. ${ }^{57}$

Although I find Thorpe's incisive reading of closure in Hodge's novel admirable, I don't share her belief that the narrator ever places her character, or the reader for that matter, in a situation where choices have to be made in terms of what is positive or negative. It is certainly true that the narrator has represented the creole world as more organic and hence sustaining of her character, but she has also expressed the inevitable distance that separates this subject and her previous world. As we saw earlier, the creole world may be culturally satisfying, but it is economically marginalized; the colonial world is culturally alienating yet it comes with important economic privileges.

My argument, then, is that by sustaining the tensions between the creole and colonial worlds instead of forcing the young Tee to choose one over the other, the author has evoked another form of ambiguity which allows history to enter her text. In other words, Tee's unstable position in Trinidad signifies the origins of displacement in a contingent historical condition that cannot, as I argued earlier, be willed out of existence. We can see this point more clearly if we recall that although Tee's adoption of Beatrice's middle class perspective accentuates her crisis of identity, it is a necessary form of self-alienation because it is the only guarantee of social mobility in a colonial situation. The world of Ma and Tantie contains traditions that are meaningful to those who live in the creole realm, but when they are transposed into the world of colonial modernity, such traditions become ossified and quite remote from the daily existence of the colonial subject. In one of the most illuminating moments in the novel, Tee returns home to bid her old friends good-bye before her departure for England only to discover that $\mathrm{Ma}$, her only link to an ancestral African past, has died: "In the last days Ma had suddenly remembered her grandmother's name and wanted it to be added to my names. Tantie hadn't even bothered to remember it" (p. 110).

The truth is, Tantie does not have the same reverence for ancestral names as Ma did. Meanwhile, Tee's more pressing problem is to deal with a rapidly changing historical situation: "Everything was chang- 
ing, unrecognizable, pushing me out. This was as it should be, since I had moved up and no longer had any place here. But it was painful, and I longed all the more to be on my way" (p. 110). Change and movement push Tee out; the moment of loss is painful, but it is shown as inevitable, "as it should be" - the logical outcome of her education. My conclusion, then, is that as a character, Tee does not make a choice to identify with the colonial English culture at the expense of her creole origins; rather, she emigrates to alienate herself from both, to find a third position from which she can now reinvent herself out of the various confluences that have socially determined her. Writing about alienation helps Tee (the narrator) understand her double consciousness.

Furthermore, if writing after colonialism is posited as a means of mastering the linguistic codes of colonial modernism, it is because the alternative to writing, as Edgell suggests in Beka Lamb, is madness or social death. Indeed, in this novel, both Beka and her friend Toycie provide contrasting forms of dealing with displacement: Toycie engages life at its most fundamental and spontaneous level-that of eros and sexuality - and thus triggers the process that leads to the mental institution and her eventual death; Beka strives to master writing, leading to the award that restores her self-esteem. But mastery of writing is not, of course, presented as a simple and singular process of liberation; on the contrary, it is cast as the result of a painful reflection on how the self (and its cultural community) are constituted in, and constitute, language. For even where the facts have been collected, there is still the problem of organizing them into a coherent narrative; it is only when all the disparate parts of the essay have been organized that the self has mastered the appropriated forms of representation. Thus the essay Beka writes is an allegory of her own struggle to rewrite herself in a world dominated by often hostile signifiers. Ironically, once she has won the essay contest she has moved closer to the colonial orb, and hence aggravated her self-alienation in the process that was supposed to pull her out of the prisonhouse of colonialism. To understand this prisonhouse more lucidly, we need to turn to the politics of representation and interpretation as they are manifested in the paradoxical relationship between history-as a project of European (and hence colonial) modernity-and the Caribbean cultural text. Michelle Cliff's Abeng provides a climactic confrontation between history and textuality. 